\title{
Characterization of Water Quality Around The New Assiut Barrage and its Hydropower Plant \\ Thabet A. Mohamed ${ }^{1}$ and Atif Abo-Elwafa ${ }^{2}$ \\ ${ }^{1}$ Environmental Engineering, STRI, Assiut University- Assiut- Egypt \\ ${ }^{2}$ Dean of Sugar Technology Research Institute, STRI, Assiut University, Egypt
}

\begin{abstract}
:
The New Assiut Barrage and its Hydropower Plant in Egypt was initiated at May, 2012 and it is suggested to endin December, 2017. The project is considered one of the most important industrial projects that established to enhance economy and development. The project energy of about $32 \mathrm{MW}$ may contribute in the main electric grid for population and developmental approaches. Surface water samples from the River Nile, around the proposed project were collected and analyzed according to EPA Method- 1669. The measured values of $\mathrm{pH}$, TDS, EC, DO, COD, Total hardness, and Temperature were recorded and reached 8.3, $183.5,317.3,7.7,19.5,135$, and $25.7{ }^{\circ} \mathrm{C}$ respectively and were compared with guidelines stated by the Egyptian law 48/ 1982 concerned with protection of River Nile from pollution. Biological properties were obtained and statistically analyzed and their sample locations were determined by Global Positioning System (GPS). The study helps the Environmental Impact Assessment in the stage of the operation of the hydroelectric power station.
\end{abstract}

Keywords: hydropower plant, physicochemical parameters, algal count, diatoms, chlorophyll, water quality, environmental impact assessment, Egypt.

Received on: $7 / 12 / 2014$

Referees: Prof. Mohsen A. Gameh
Accepted for publication on: 13/1/2015

Prof. Abd elhay A. Farag 


\section{Introduction:}

The Assiut Barrage was constructed between 1892 and 1902 to sustain a water level difference of about $4 \mathrm{~m}$ in order to feed the Ibrahimia canal (length about $350 \mathrm{~km}$ ) which irrigates an area of almost 600,000 ha. The barrage was remodeled by 1930 to increase the permissible head pond level difference to $4.2 \mathrm{~m}$ and thereby increasing the capacity of the Ibrahimia canal. The civil works have been affected by age and also by tail water erosion as a consequence of a modified river regime after the construction of the Aswan High Dam.

The government of Egypt intends to replace the existing barrage with a new structure incorporating a hydropower plant. After studying various alternatives, the Egyptian government decided to construct a multipurpose barrage to guarantee the supply of irrigation, to generate hydropower, and to increase navigation capacity for river traffic. It consists of a sluiceway to evacuate emergency flood release, a hydropower plant, a double navigation lock and a road bridge.

The project scope of works: the construction of 2 navigation locks of $150 \times 17 \mathrm{~m}$ according to the latest international technologies to accommodate the increase in the river and tourism transport units; the construction of a 4- lanes upper bridge over the new barrage with capacity 70 tons to link the East and West banks of the River Nile in Assiut. The barrage project components are: Sluiceway with 8 radial gates $17 \mathrm{~m}$ wide and Road Bridge; Hydropower plant: Low-head hydropower plant with 4 bulb units of $8 \mathrm{MW}$, total capacity 32 MW; new navigation lock: 120x17 m chamber in addition to the refurbished 80 x 16 m high; Rehabilitation of the existing navigation lock: Replacement and Rehabilitation of the existing Ibrahimia canal head regulator: and Transmission line. The project of New Assiut Barrage and its Hydropower Plant has very promising positive aspects in relation to sustainable development, poverty alleviation, social and economic development in Egypt (Batisha (2007).

The impact of hydroelectric power plant on the environment is varied and depends upon the size and the type of the project. Although hydropower generation does not burn any fuel to produce power and hence des not emit greenhouse gases, there are definite negative effects that arise from the creation of the reservoir and alteration of natural water flow. It is a fact that dams, inter-basin transfers and diversion of water for irrigation purposes have resulted in the fragmentation of $60 \%$ of the world's rivers (Alobeidy et al., 2010).

The sediment in the reservoir in the front of the hydropower station plays an important role in degradation of water quality. Sediment diagenesis may reduce the organic matter content by bacterial degradation linked to methanogenesis, oxidation and $\mathrm{CO}_{2}$ production, and other processes (Bhatt et al., 2011). Sediment erosion within the reservoir depends on hydrodynamics, mainly on stream velocity in river reservoir and thus on the river load. (Chindeu et al., 2011) reported that remobilization of contaminants from sediments and their return to the trophic chain, either by sediment erosion, by uptake by organisms (fish, plants and sediment dwellers), or by infiltration of interstitial water from the sediment to the 
ground water. Also Jena et al., 2013, showed that reduction of nutrients inputs to coastal areas of oceans and seas, resulting in reduced primary production in offshore areas. This may affect the marine carbon balance through limitation of production, and therefore climate change. Oxygen depletion by the oxidation of particulate and dissolved organic carbon may lead to deoxygenated or even anoxic conditions in deep water and in sediment (Bhatt et al., 2011). The main hazards associated with this are: eutrophication of deep reservoir water, remobilization of nutrients, metals and organic contaminants from sediments and their availability to organisms (plants, sediment dwellers), and infiltration of pore water charged with contaminants and organic carbon to the ground water (El-Ayouti and Abo-Ali, 2013).

The chemistry of physicochemical parameters and biological characteristics play a discriminative role for assessment of water quality in the vicinity of the hydropower plant area. Water quality parameters like temperature, $\mathrm{pH}$, total dissolved solids, electric conductivity, dis- solved oxygen, turbidity, hardness, chemical oxygen demand, $\mathrm{Ca}, \mathrm{Mg}, \mathrm{K}$, $\mathrm{Na}$ were measured and compared with guidelines stated by $\mathrm{WHO}$ and EC standards and with the Egyptian law 48/1982 concerned with protection of the River Nile from pollution (WHO, 2004).

A major impact on surface water quality may stem from biological processes such as bacterial contamination due to the release of water from wastewater treatment plants and diffuse run-off. Also, in particular conditions, sediment contamination may contribute to the persistence of contamination in the overlying water (Mananda et al., 2010). Water turbidity can be increased by high plankton and algal concentrations and there may be a proliferation of mosquitoes and other insects leading to the risk of spreading malaria. Thus the study now focuses to identify impacts on river water quality regarding physicochemical and biological characteristics making a comparative analysis withfuture studies of the Environmental Impact Assessment of the project. Figure (1) illustrates the proposed project.

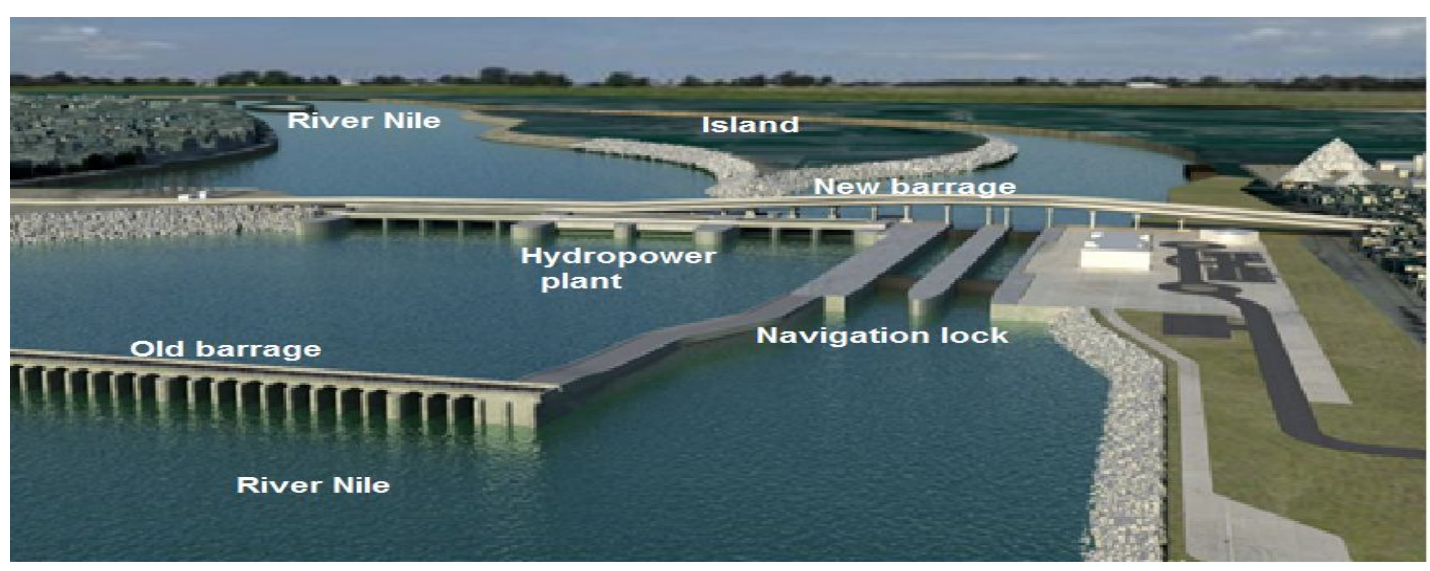

Figure (1): The proposed project of New Assiut Barrage and its Hydropower plant 
2. Materials and Methods:

\subsection{Site description}

The government of Egypt is replacing the existing Assuit barrage in Upper Egypt with a new structure incorporating a power plant. The old barrage was constructed in the year of 1902 to reserve water for irrigation of farmland in the region. Over the years the riverbed has degraded, especially after commissioning of the Aswan High Dam, and the stability of the barrage may eventually be threatened during low flow periods. This lead to the decision to construct a new barrage and is making use of the water energy with a power plant. The location stated at $\left(27^{\circ} 12^{\prime} 19^{\prime \prime} \mathrm{N}, 31^{\circ} 11^{\prime}\right.$ $26^{\prime \prime} \mathrm{E}$ ) is at the river approximate$1 y 400 \mathrm{~km}$ downstream of the old barrage in North-east of Assuit city. Figure (2) shows the construction pitfor the New Assuit Barrage and the Hydropower Plant.

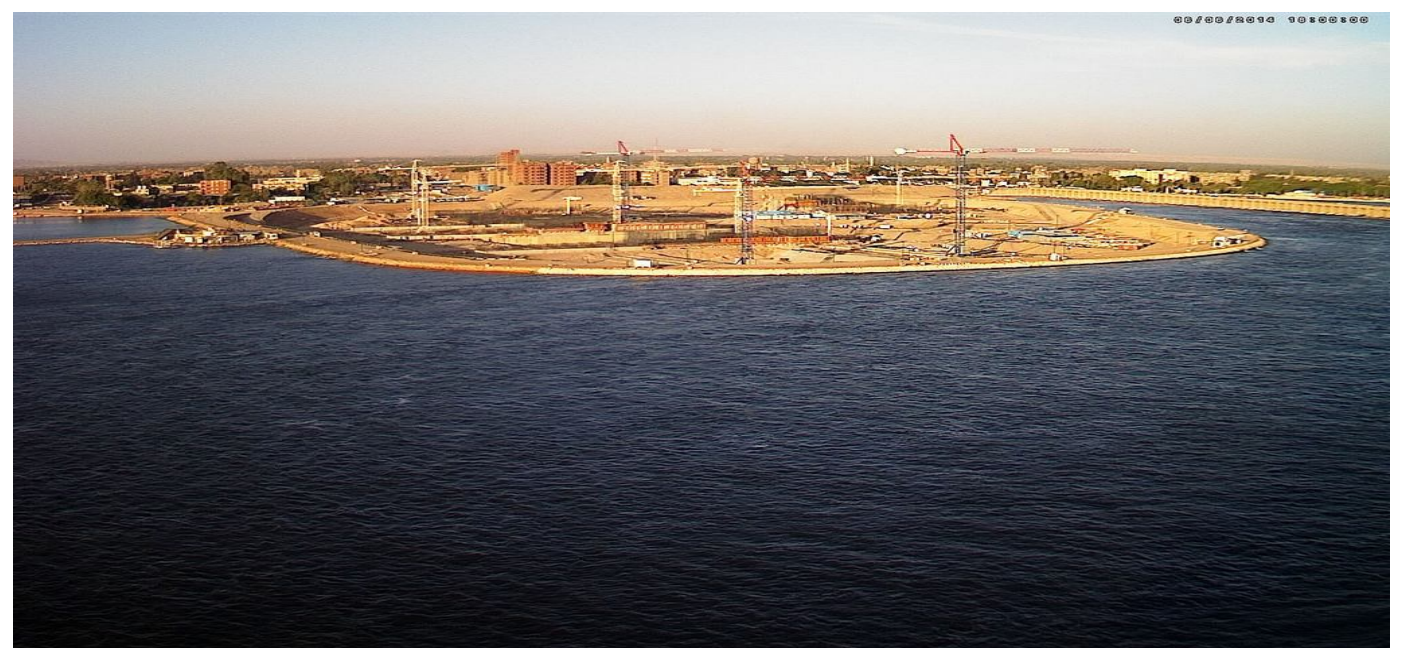

Figure (2): The construction pit for the New Assiut Barrage and Hydropower Plant

\subsection{Collection of water samples}

As shown in Table (1), water quality parameters such as temperature, $\mathrm{pH}$, total dissolved solids (TDS), total suspended solids (TSS), dissolved oxygen (DO), and conductivity were measured in the water samples taken from the sites around the project, using a thermometer, $\mathrm{pH}$ me- ter, conductivity-meter and TDS meter respectively (Mahananda et al., 2010). For dissolved oxygen (DO), samples were collected into $300 \mathrm{ml}$ plain glass bottles and the DO fixed using the azide modification of the Winkler's method (Chindeu et al., 2011). 
Table (1): Water quality test methods and test units

\begin{tabular}{|c|c|c|}
\hline Parameters & Test unit & Method \\
\hline $\mathrm{PH}^{*}$ & - & Thermometer \\
\hline Temperature* & $\mathrm{C}$ & Electrometric \\
\hline Turbidity & NTU & Spectrophotometric \\
\hline Electrical conductivity $^{*}$ & $\mu \mathrm{S} / \mathrm{cm}$ & Electrometric \\
\hline Total dissolved solids ${ }^{*}$ & $\mathrm{mg} / \mathrm{l}$ & Electrometric \\
\hline Total suspended solids & $\mathrm{mg} / \mathrm{l}$ & Filtration \\
\hline Total alkalinity & $\begin{array}{c}\mathrm{mg} / \mathrm{l} \text { as } \mathrm{Ca}- \\
\mathrm{CO}_{3}\end{array}$ & Titration \& Electrometric \\
\hline Total hardness & $\begin{array}{c}\mathrm{mg} / \mathrm{l} \text { as } \mathrm{Ca}- \\
\mathrm{CO}_{3}\end{array}$ & Titration, Na EDTA \\
\hline Total Nitrogen & $\mathrm{mg} / \mathrm{l}$ & Kjeldabl method \\
\hline Lead $(\mathrm{Pb})$ & $\mathrm{mg} / \mathrm{l}$ & $\begin{array}{l}\text { Atomic absorption Spectrophoto- } \\
\text { metric }\end{array}$ \\
\hline Dissolved oxygen(DO) & $\mathrm{mg} / \mathrm{l}$ & Titration and Electro-photometric \\
\hline Chemical oxygen demand (COD) & $\mathrm{mg} / 1$ & $\mathrm{~K}_{2} \mathrm{Cr}_{2} \mathrm{O}_{7}$ Digestion \\
\hline Biological oxygen demand (BOD) & $\mathrm{mg} / \mathrm{l}$ & 5 days incubation \\
\hline Total Coli- form & $\mathrm{CFU} / 100 \mathrm{ml}$ & Membrane filter \\
\hline Fecal Coli- form & $\mathrm{CFU} / 100 \mathrm{ml}$ & Membrane filter \\
\hline
\end{tabular}

Samples of bacteriological analysis were collected into sterilized plain glass bottles. All samples were stored in icebox and transported to the National Research Center (Water Pollution Research Unit Laboratories). The results obtained were also compared against the threshold values of WHO (2004), National drinking water quality (NDWQS 2062 B.S.) and guidelines set by the European Union (EU). Descriptive statistics of the data set are presented in Table (6) and were carried out to simplify its interpretation and to define the parameters responsible for the main variability in water quality variance (Verma et al., 2012)). Also correlation factors for water quality parameters were determined to reveal much more about the combination of any parameters that are more affective on water quality. Mean values of different physicochemical and biological characteristics (Mean \pm SD and range) are shown in Table (3).

\subsection{Statistical analysis}

The obtained data were processed statistically using the software SPSS. 16. Standard Deviation $\mathrm{SD}$, the mean, the minimum, the maximum and the range values were determined.

\subsection{Biological characteristics}

Eight stations were chosen for samples of Algae (Figure 3) on basis of the 4 sites located upstream and the other four sites located downstream of the existing barrage of the River Nile and around the project site. 
Table (2): shows the sampling locations and GPS coordinates

\begin{tabular}{|c|c|c|c|}
\hline Long. E & Lat. $\mathbf{N}$ & Location & No. \\
\hline $31^{\circ} \quad 11^{\prime} 34^{\prime \prime}$ & $27^{\circ} \quad 11^{\prime} \quad 21^{\prime \prime}$ & $\begin{array}{l}1.5 \mathrm{~km} \text { upstream of existing barrage } \\
\text { In the east side of the river }\end{array}$ & $\mathrm{S}_{1}$ \\
\hline $31^{\circ} \quad 11^{\prime} \quad 42^{\prime \prime}$ & $27^{\circ} 11^{\prime} \quad 25^{\prime \prime}$ & $\begin{array}{l}1.5 \text { upstream of existing barrage in } \\
\text { West side of the river }\end{array}$ & $\mathrm{S}_{2}$ \\
\hline $31^{\circ} 11^{\prime} 28^{\prime \prime}$ & $27^{\circ} \quad 11^{\prime} \quad 34^{\prime \prime}$ & $\begin{array}{l}1 \mathrm{~km} \text { upstream of existing barrage } \\
\text { In the east side of the river }\end{array}$ & $\mathrm{S}_{3}$ \\
\hline $31^{\circ} 11^{\prime} \quad 35^{\prime \prime}$ & $27^{\circ} \quad 11^{\prime} \quad 40^{\prime \prime}$ & $\begin{array}{l}1 \mathrm{~km} \text { upstream of existing barrage } \\
\text { In the west side of the river Nile }\end{array}$ & $\mathrm{S}_{4}$ \\
\hline $31^{\circ} 11^{\prime} \quad 32^{\prime \prime}$ & $27^{\circ} \quad 12^{\prime} \quad 58^{\prime \prime}$ & $\begin{array}{l}1.6 \mathrm{~km} \text { downstream of Assuit new bar- } \\
\text { rage, in the west side }\end{array}$ & $\mathrm{S}_{5}$ \\
\hline $31^{\circ} \quad 9^{\prime}$ & $27^{\circ} \quad 12^{\prime}$ & $\begin{array}{c}3 \mathrm{~km} \text { downstream of Assuit new bar- } \\
\text { rage }\end{array}$ & $\mathrm{S}_{6}$ \\
\hline $\begin{array}{lll}31^{\circ} & 10^{\prime} & 34^{\prime \prime}\end{array}$ & $27^{\circ} \quad 12^{\prime}$ & $\begin{array}{l}1.4 \mathrm{~km} \text { downstream of Assuit barrage, } \\
\text { west side }\end{array}$ & $\mathrm{S}_{7}$ \\
\hline $31^{\circ} \quad 10^{\prime} \quad 51^{\prime \prime}$ & $27^{\circ} \quad 12^{\prime} \quad 28^{\prime \prime}$ & $\begin{array}{l}1 \mathrm{~km} \text { downstream of new Assuit bar- } \\
\text { rage, east side }\end{array}$ & $\mathrm{S}_{8}$ \\
\hline
\end{tabular}

Global Position System (GPS) device (Garmin 62s) was used to define the coordinates of these sites as shown in Table (2).

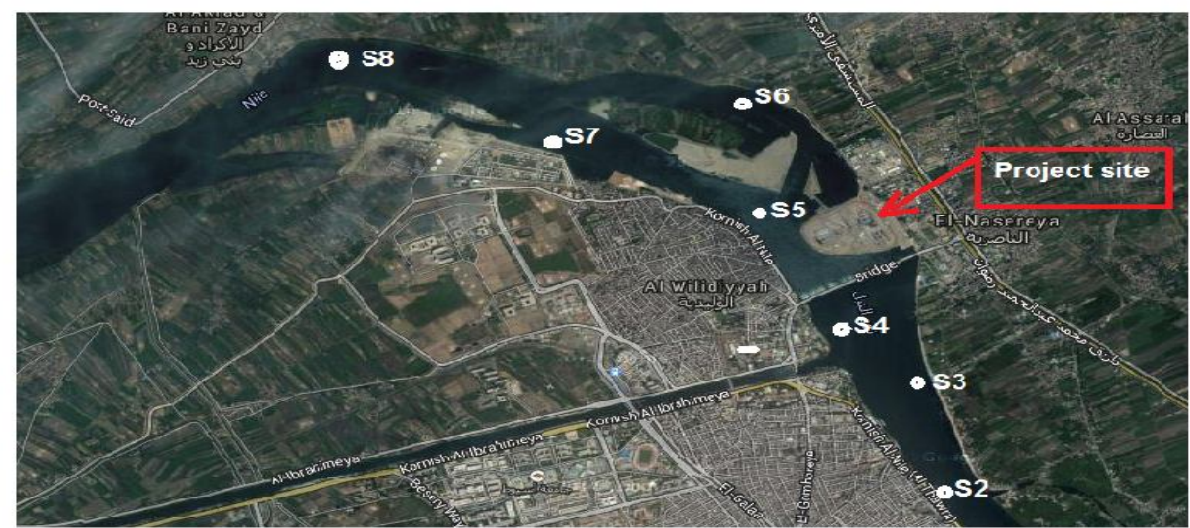

Figure (3): A map showing the project site and water sample locations

\section{Results and Discussions}

\subsection{Physicochemical Parameters}

\subsubsection{Temperature}

Temperature of surface water around the project of the New Assiut Barrage and its Hydropower station varies from $23.8{ }^{\mathrm{O}} \mathrm{C}$ to $27.6{ }^{\mathrm{O}} \mathrm{C}$ with an average value of $25.7^{\circ} \mathrm{C}$ as shown in Table (4). The average value lies within the allowable levels where temperature of water in streams and rivers through out the worldvaries from 0 to $35{ }^{\mathrm{O}} \mathrm{C}$. The temperatures of water affects some of the important physical properties and characteristics of water: thermal capacity, density, specific weight, viscosity, surface tension, specific conductivity, salinity and solubility of dissolved gases and etc. (Mustafa and Aris, 2011). Chem- 
ical and biological reaction rates increase with increasing temperature. Reaction rates usually assumed to double for an increase in temperature of $10^{\circ} \mathrm{C}$.

\section{$3.1 .2 \mathrm{pH}$}

Acidity indicates the corrosiveness of acidic water on steel, concrete and other materials. The average value of $\mathrm{p} \mathrm{H}$ was 8.3 where it varies in water sample analysis from 8.1 to 8.5 and not exceeded the limits $(6.8-$ 8.5) stated by the USEPA and the standards suggested by the Egyptian law48/1982 ( $\mathrm{pH}=7.8)$.

\subsubsection{Total Hardness}

The total hardness in surface water samples ranged from 130-140 $\mathrm{mg} / \mathrm{l}$ with an average value of 135 $\mathrm{mg} / \mathrm{l}$ showing a moderately hardness as indicated in Table (4). The slight increase of hardness can be interprted by the dissolved solids from construction works and the industrial wastewater resulting from washing sand and gravel and releasesinto the river water.Hardness is correlated with TDS (Total dissolved solids). It represents total concentration of $\mathrm{Ca}^{2+}$ and $\mathrm{Mg}^{2+}$ ions, and is reported in equivalent $\mathrm{CaCO}_{3}$. Other ions $\left(\mathrm{Fe}^{2+}\right)$ may also contribute. Hardness expressed as $\mathrm{mg} / \mathrm{L} \mathrm{CaCO}_{3}$ is used to classify waters from "soft" to "very hard". This classification is summarized in Table (3).

Table (3): Hardness Concentration and Classification of Natural water (Hem, 1971)

\begin{tabular}{|c|c|}
\hline Hardness as $\mathbf{~ m g} / \mathbf{L}$ & Classification \\
\hline $0-60$ & Soft \\
\hline $61-120$ & Moderately hard \\
\hline $121-180$ & Hard \\
\hline$>180$ & Very hard \\
\hline
\end{tabular}

Hardness observed for streams and rivers throughout the world ranges between 1 to $1000 \mathrm{mg} / \mathrm{l}$. Typical concentrations are $47 \mathrm{mg} / \mathrm{l}$ to 74 $\mathrm{mg} / \mathrm{l} \mathrm{CaCO}_{3}$ (WHO, 2004).Hardness is an indicator to industry of potential precipitation of calcium carbonates in cooling towers and boilers, interference with soaps and dyes in cleaning and textile industries and with emulsifiers in photographic development. Hard water is less corrosive than soft. Treatment usually left to consumer (domestic, industrial, etc.) depending on needs.

\subsubsection{Total Dissolved Solids}

The mean value of total dissolved solids TDS was $183.5 \mathrm{mg} / \mathrm{l}$ , less than the permissible level stated by the Egyptian law 48/1982 (500 $\mathrm{mg} / \mathrm{l}$ ), and also less than the value suggested by USEPA $(500 \mathrm{mg} / \mathrm{l})$. Total dissolved solids (TDS) are a measure of salt dissolved in a water sample after removal of suspended solids. TDS is residue remaining after evaporation of the water. The TDS load carried in streams throughout the world has been estimated by Tcgobanoglous (1985) to 120 $\mathrm{mg} / \mathrm{L}$.Turbidity is a measure of the light-transmitting properties of water and is comprised of suspended and colloidal material. It is important for health and aesthetic reasons.

The concentration of total dissolved solids (TDS) is related to electrical conductivity $(\mathrm{EC} ; \mu \mathrm{S} / \mathrm{cm})$ or 
specific conductance. The conductivity measures the capacity of water to transmit electrical current. The conductivity is a relative term and the relationship between the TDS concentration and conductivity is unique to a given water sample and in a specific TDS concentration range. The conductivity increases as the concentration of TDS increase. TDS and conductivity affect the water sample and the solubility of slightly soluble compounds and gases in water (e.g. $\mathrm{CaCO}_{3}$, and $\mathrm{O}_{2}$ ). In general, the corrosiveness of the water increases as TDS and EC increase, assuming other variables are kept constant.

\subsubsection{Electrical Conductivity}

The value of electrical conductivity EC varies from 285 to $330 \mu \mathrm{S} / \mathrm{cm}$ with an average value of $317.8 \mu \mathrm{S} / \mathrm{cm}$. EC is the measure of cations and anions in water samples and shows the concentration of dissolved salts which it contributes in prediction of water quality. The Egyptian law 48/1982 for River Nile Protection from Pollution stated that the $\mathrm{EC}>5 \mu \mathrm{S} / \mathrm{cm}$, where the Food and Agriculture Organization FAO suggested the value of $\mathrm{EC}$ to be $<3$ $\mu \mathrm{S} / \mathrm{cm}$.

\subsubsection{Dissolved Oxygen}

The measured values of dissolved oxygen varies from 7.6 to
$7.8 \mathrm{mg} / \mathrm{l}$ with average value of 7.7 $\mathrm{mg} / \mathrm{l}$ as shown in Table (4).Typical dissolved oxygen concentrations observed in streams and rivers throughout the world are 3 to $9 \mathrm{mg} / \mathrm{l}$. The observed range of dissolved oxygen concentrations is $0 \mathrm{mg} / \mathrm{L}$ (anoxic conditions) to $19 \mathrm{mg} / \mathrm{L}$ (supersaturated conditions).Dissolved oxygen is important in natural water because many microorganisms and fish require it in aquatic system. Dissolved oxygen also establishes an aerobic environment in which oxidized forms of many constituents in water are predominant. Under anoxic conditions in water, reduced forms of chemical species are formed and frequently lead to the release of undesirable odors in water (Wahaab and Badway, 2004). Thus the study now focuses to identify impacts on river water quality regarding physicochemical and biological characteristics making a comparative analysis with the studies of the Environmental Impact Assessment will be carried out during operational phase of the project.It is revealed that most physico-chemical parameters are coincide with permissible levels for water drinking according to guidelines stated by the WHO or USEPA for water quality assessment. 
Table (4): Statistical analysis of physico-chemical parameters

\begin{tabular}{|c|c|c|c|c|c|}
\hline Parameter & Min. & Max. & Mean & SD & Range \\
\hline $\mathrm{pH}$ & 8.1 & 8.5 & 8.3 & 0.28 & $8.1-8.5$ \\
\hline $\mathrm{EC}$ & 285 & 330 & 317.3 & 31.8 & $285-330$ \\
\hline $\mathrm{T}\left({ }^{\circ} \mathrm{C}\right)$ & 23.8 & 27.6 & 25.7 & 0.68 & $23.8-27.6$ \\
\hline $\mathrm{TDS}$ & 175 & 192 & 183.5 & 12.02 & $175-192$ \\
\hline $\mathrm{DO}$ & 7.6 & 7.8 & 7.7 & 0.14 & $7.6-7.8$ \\
\hline $\mathrm{HCO}_{3}$ & 130 & 140 & 135 & 7.07 & $130-140$ \\
\hline $\mathrm{SO}_{4}^{2-}$ & 0.3 & 29 & 20 & 7.4 & $0.3-29$ \\
\hline $\mathrm{Cl}^{-}$ & 14 & 20 & 16.4 & 1.0 & $14-20$ \\
\hline $\mathrm{COD}^{\mathrm{Ca}}$ & 18 & 21 & 19.5 & 2.12 & $18-21$ \\
\hline $\mathrm{Mg}$ & 24 & 28 & 26 & 2.82 & $24-28$ \\
\hline $\mathrm{K}$ & 12 & 16.7 & 14.4 & 3.32 & $12-16.7$ \\
\hline $\mathrm{Na}$ & 5 & 5.1 & 5.05 & 0.07 & $5-5.1$ \\
\hline & 30 & 35.6 & 32.15 & 3.23 & $30-35.6$ \\
\hline
\end{tabular}

\section{mand \\ 3.1.7 Chemical Oxygen De-}

Measurements of water quality samples of surface water showed that Chemical Oxygen Demand COD reached the value of $19.5 \mathrm{mg} / \mathrm{l}$ and varies from 18 to $21 \mathrm{mg} / \mathrm{l}$. The allowable level for COD stated by the law $48 / 1982$ is $<10-15$. The slight increase in the measured values is due to consumption of oxygen taken up by aquatic organisms in water to digest the organic matter released from construction works.

\subsubsection{Major Cations}

The major cationswere found in surface water samples of calcium $\mathrm{Ca}^{2+}$, magnesium $\mathrm{Mg}^{2+}$, sodium $\mathrm{Na}^{+}$ and $\mathrm{K}^{+}$with the average value of 26 , $14.4,32.15$ and $5.05 \mathrm{mg} / 1$ respectively. Calcium is the most prevalent cation in water where it varies from 24 to $28 \mathrm{mg} / \mathrm{l}$ and second inorganic ion to bicarbonate in most surface water. Calcium is considered the primary constituent of water hardness and precipitates as $\mathrm{CaCO}_{3}$ in iron and steel pipes. A thin layer of $\mathrm{CaCO}_{3}$ can help inhibit corrosion of the metal. However, excessive accumulation of $\mathrm{CaCO}_{3}$ in boilers, hot water heater, heat exchangers and associated piping affects heat transfer and could lead to plugging of the piping. However, calcium concentrations of 40 to $120 \mathrm{mg} / \mathrm{l}$ are more common (Tandale and Mujawar, 2014).

Magnesium is not abundant in rocks as calcium. Therefore, although magnesium salts are more soluble than calcium, less magnesium is found in surface water. The concentration of value of magnesium reached $14.4 \mathrm{mgl}$ as have been mentioned above, but distribution of magnesium cations in water samples ranges from 12 to $16.7 \mathrm{mg} / \mathrm{l}$ and sodium and potassium varies from 30 to 35.6 and 5 to $5.1 \mathrm{mg} / \mathrm{l}$ respectively.

\subsubsection{Major Anions}

The average values of chloride, sulfate, bicarbonate and nitrate anions were $16,14.6,135$ and $0.76 \mathrm{mg} / \mathrm{l} \mathrm{re}-$ spectively, as shown in table 4 . Bicarbonate $\mathrm{HCO}_{3}^{-}$is the principal anion found in natural water. These 
ions are very important in the carbonate system, which provides a buffer capacity to natural water and is responsible in a great measure for the alkalinity of water. One source of bicarbonate ions $\mathrm{HCO}_{3}{ }^{-}$in surface water is the dissociation of carbonic acid $\mathrm{H}_{2} \mathrm{CO}_{3}$ that is formed when carbon dioxide $\mathrm{CO}_{2}$ from the atmosphere, or from animals (e.g. fish) and bacterial respiration, dissolves in water.

In addition to bicarbonate anions, such as chloride $\mathrm{Cl}^{-}$, sulfates $\mathrm{SO}_{4}{ }^{2-}$ and nitrates $\mathrm{NO}_{3}{ }^{-}$are commonly found in surface water. These anions are released during the dissolution and dissociation of common salt deposits in geologic formation. The value of chlorides measured in water samples ranged from 14 to 20 $\mathrm{mg} / \mathrm{l}$, with an average value of 16.4 $\mathrm{mg} / \mathrm{l}$. The concentration of chloride anions $\mathrm{Cl}^{-}$determines the water quality because the quality of water was $\mathrm{mg} / \mathrm{l}$, where the worse after increasing in the concentration of these anions which limit possibilities of using of natural water for different purposes (household, agriculture, industry and etc.). Principal source of chloride anions $\mathrm{Cl}^{-}$in surface water are magmatic rock formations that include chlorine- content minerals. The second source of this anions is Ward Ocean from where a considerably amount of chloride anions enter in the atmosphere. From atmosphere chloride anions $\mathrm{Cl}^{-}$enter the surface water in result of interaction between precipitation and soil.

The sulfate anions $\mathrm{SO}_{4}{ }^{2+}$ are frequently found in surface water as the results of the substances from plant and animal origin. The increase concentration of the sulfate anions, at one hand brings about change for the worse of some physical characteris- tics of water (taste, smell and etc.) and on the other hand has destructive influence upon human consumption. The measured value of sulfates was $14.6 \mathrm{mg} / \mathrm{l}$ and it varies from 25 to 29 $\mathrm{mg} / \mathrm{l}$ in water samples. The concentration of sulfate anions $\mathrm{SO}_{4}{ }^{2-}$ fluctuates in a wide range in surface water from 5 to $60 \mathrm{mg} / \mathrm{l}$ (Tandale and Mujawar, 2014).

The measured value of nitrates $\mathrm{NO}_{3}{ }^{-}$in surface water around the New Assiut Barrage and its Hydropower Plant was $0.79 \mathrm{mg} / \mathrm{l}$, but the nitrate distribution in water area under investigation varies from 0.06 to $2 \mathrm{mg} / \mathrm{l}$. Nitrate anions $\mathrm{NO}_{3}{ }^{-}$are found in surface water as a result of bacteriological oxidation of nitrogenous materials in soil. That is why the concentration of these anions rapidly increases in summer when the process of nitrification takes place very intensively. Another important source for dressing of the surface water with nitrate anions is precipitation, which absorb nitric oxides and convert them into nitric acid. A great deal of nitrate anions enters in surface water together with domestic water and water from industry, agriculture and etc (Jena et al., 2013). Nitrate anions are one of the indicators for the degree of the pollution with organic nitratecontent substances.

\subsubsection{Correlation Coefficient}

The correlation coefficients of physico- chemical parameters of water samples were calculated and depicted in Table (5).It was found that there is a significant correlation in the following systems: $\mathrm{EC}-\mathrm{TDS}(\mathrm{r}=0.98)$, Na- $\mathrm{T}^{\mathrm{O}}(\mathrm{r}=0.60), \mathrm{T}^{\mathrm{O}}-\mathrm{Ca}(\mathrm{r}=0.89)$, TDS- $\mathrm{Na}(\mathrm{r}=0.56), \mathrm{NO}_{3}-\mathrm{Mg}(\mathrm{r}=0.78)$ and $\mathrm{HCO}_{3}-\mathrm{SO}_{4}(\mathrm{r}=0.77)$ etc. It can be concluded that the total dissolved solids in presence of raised tempera- 
ture, may enhance the solubility of particles to give more turbidity to the water system. This deteriorates water supply intake and pumps of irrigation system. Also its have been noted from statistical analysis that EC present in water with high level leads to dissolve of water salts giving in- crease in salinity of water.So working in rivers and lakes requires more strict regulations for dust release in waters. Table (5) shows the correlation coefficients of physico-chemical properties.

Table (5): Correlation coefficients of physico-chemical parameter

\begin{tabular}{|c|c|c|c|c|c|c|c|c|c|c|c|c|c|}
\hline & $\mathbf{p H}$ & $\mathbf{E C}$ & $\mathbf{T}{ }^{\circ} \mathbf{C}$ & $\mathbf{T D S}$ & $\mathbf{D O}$ & $\mathbf{H C O}$ & $\mathbf{C O D}$ & $\mathbf{C a}$ & $\mathbf{M g}$ & $\mathbf{K}$ & $\mathbf{N a}$ & $\mathbf{S O}_{4}$ & $\mathbf{N O}_{3}$ \\
\hline $\mathrm{pH}$ & 1 & -0.6 & -0.10 & -0.72 & 0.059 & 0.60 & 0.36 & -0.23 & -0.19 & -0.83 & -0.02 & 0.14 & 0.35 \\
\hline $\mathrm{EC}$ & & 1 & -0.18 & 0.98 & -0.24 & -0.73 & 0.32 & -0.014 & 0.079 & 0.27 & 0.60 & -0.60 & 0.16 \\
\hline $\mathrm{T}{ }^{\circ} \mathrm{C}$ & & & 1 & -0.12 & 0.41 & -0.10 & 0.29 & 0.89 & -0.77 & -0.20 & -0.29 & 0.34 & -0.99 \\
\hline $\mathrm{TDS}$ & & & & 1 & -0.32 & -0.70 & 0.21 & -0.05 & 0.03 & 0.40 & 0.56 & -0.45 & 0.10 \\
\hline $\mathrm{DO}$ & & & & & 1 & 0.11 & 0.11 & 0.30 & -0.22 & -0.2 & -0.22 & -0.66 & -0.4 \\
\hline $\mathrm{HCO}_{3}$ & & & & & 1 & 0.31 & -0.50 & -0.15 & -0.33 & 0.02 & 0.77 & 0.11 \\
\hline $\mathrm{COD}$ & & & & & & & 1 & 0.35 & -0.55 & -0.75 & 0.39 & -0.7 & -0.30 \\
\hline $\mathrm{Ca}$ & & & & & & & & 1 & 0.53 & -0.02 & -0.49 & -0.60 & -0.84 \\
\hline $\mathrm{Mg}$ & & & & & & & & & 1 & 0.52 & -013 & 0.08 & 0.78 \\
\hline $\mathrm{K}$ & & & & & & & & & & 1 & -0.28 & -0.23 & 0.2 \\
\hline $\mathrm{Na}$ & & & & & & & & & & & 1 & -0.05 & 0.28 \\
\hline $\mathrm{SO}_{4}$ & & & & & & & & & & & 1 & 0.35 \\
\hline $\mathrm{NO}_{3}$ & & & & & & & & & & & & 1 \\
\hline
\end{tabular}

Table (6): Biological properties and their statistical analysis

\begin{tabular}{|c|c|c|c|}
\hline Parameters \& Date & Total green algal & Diatoms & Chlorophyll \\
\hline $1 / 1 / 2014$ & 3955 & 3933 & 13.5 \\
\hline $1 / 2 / 2014$ & 972 & 885 & 1.78 \\
\hline $1 / 3 / 2014$ & 246 & 211 & 1.78 \\
\hline $1 / 4 / 2014$ & 791 & 307 & 17.4 \\
\hline $1 / 5 / 2014$ & 4863 & 4546 & 11.7 \\
\hline $1 / 6 / 2014$ & 3300 & 2700 & $12.4^{*}$ \\
\hline $1 / 7 / 2014$ & 2605 & 860 & 18.3 \\
\hline $1 / 8 / 2014$ & 3404 & 2700 & 17.6 \\
\hline $1 / 9 / 2014$ & 820 & 3404 & 10.9 \\
\hline $1 / 10 / 2014$ & 370 & 704 & 17.2 \\
\hline $1 / 11 / 2014$ & 2113 & 808 & 18.6 \\
\hline $1 / 12 / 2014$ & 995 & 2115 & 20.1 \\
\hline Min. & 995 & 2115 & 13.5 \\
\hline Max. & 3955 & 3933 & 20.1 \\
\hline Mean & 2475 & 3024 & 16.8 \\
\hline SD & 20.039 & 12.85 & 4.66 \\
\hline
\end{tabular}




\subsection{Biological Characteristics}

Biological characteristics of water samples surrounding the project of the new Asyut barrage and its hydropower plant were studied and it was found an abundance of green algal count, blue - green algal and diatoms. This enrichment is due to dissolved of organic species and phosphorus and nitrogen as nutrients of microorganisms. Table (6) shows the results of different algal counts in water samples.

\section{Conclusion:}

This study is an attempt to evaluate the water quality in the River Nile around the New Assuit Barrage and its Hydroelectric Station using analysis of the physicochemical and biological characteristics. The following points were concluded:

1. The physicochemical parameters measured of the surface water upstream and downstream of the barrages lie within the permissible limits according to the Article (49) of decree No. 92/ 2013 of law 48 of 1982 on the protection of the River Nile from pollution.

2. In some points of the investigated area observed that the clarity of water has impaired due to turbidity, TDS, and TSS resulting from project construction works. This situation is lasted through settlement of debris and dilution of the river but for the suspended particles it may travel to long distances downstream across the river.

3. Algal counts increase in water body due to the solubility of nutrients of organic species and this may leads to eutrophication and increase consumption of the dissolved oxygen and this deteriorates the aquatic organisms. Also the abundance of algae in waters leads to more turbidity in water systems.

\section{Acknowledgement}

The authors would like to express their deep gratitude toMr. Karl ShwarzAndritz Hydro Contractor Representative (Austria) and to Eng. Ahmed Saied, the Executive Manager of Hideleco (Egypt). Also thanks are extended to Ministry of Irrigation and Water Resources, especially for Eng.Abdel- Rahiemthe General Manager of Safety and Environmental Studies of RGBSfor their sincere cooperation during preparing this work.

\section{References:}

.Alobeidy, A-H., M., Abid, H.S., Maulood, B.K. (2010). Application of water quality index for assessment of Dokan Lake Ecosystem, Kurdistan Region, Iraq.Journal of Water Resources and Protection, 2, 792- 798.

Batisha, A.F. (2007). Water quality analysis of water structures projects. Case study: New NegaHamadi Barrage in Egypt. Eleventh International Water Technology Conference, IWTC 2007Sharm El-Shiekh, Egypt 1009.

Bhatt, R.P., Khanal, S.N., and Maskey, R. K. (2011). Water quality impacts of hydropower project operation in Bhotekoshi river basin Sindhlpalchowk District in Nepal. International Journal of Plant, Animal and Environmental Sciences,1(1): 88- 101.

Chindeu, S.N., Nwinyi, O.C., Oluwadamisi, A.Y. and Eze, V.N. (2011).Assessment of water quality in Canaanland, Ota, Southwest Nigeria. Agri. BIOL. J. N. AM, 2(4): 577- 583. 
El- Ayouti, A. and Abo- Ali, H. (2013).Spatial heterogeneity of the Nile water quality in Egypt.Journal of Environmental Statistics, 4(8).

Hem (1971). The chemistry of heterocyclic compounds, Quinazolines: Supplement 1. John Wiley and Sons, U.S., Ch.2, pp. 151160.

Jena, V., Dixit, S. and Gupta, S. (2013).Assessment of water quality index of industrial area surface water samples. International Journal of Chem Tech research ,5(1): 278- 283.

Mahananda, M.R., Mohanty, B.P. and Behera, N.R. (2010).Physicochemical analysis of surface and ground water of Baragarh District, Orissa, India. IJRRAS,2(3)

Mustapha, A., and Aris, A.Z. (2011).Spatial aspect of surface water quality using chemometric analysis. Journal of Applied Sciences in Environmental Sanitation, 6(4): 411- 426.

Tandale, S.M. and Mujawar, H.A. (2014).Assessment of surface water quality in the vicinity of an industrial area near village Datav of Raigad, Maharash-
tra.International Journal of Research in Engineering and Technology, 3(4).

Tcgobanoglous, G., Schroeder, and Edward, D. (1985). Water quality: Characteristics, Modeling, Modification, Prentice Hall, U.S., 1985.

Verma, O., Khanan, B. and Skula, S. (2012). Determination of physic- chemical characteristics of four canals of Allahabad region and its suitability for irrigation. Advances in Applied Science Research, 3(3): 1531- 1537.

Verma, o., Khanan, B. and Skula, S. (2012).Determination of physicchemical characteristics of four canals of Allahabad region and its suitability for irrigation. Advances in Applied Science Research, 3(3): 1531- 1537.

Wahaab, R.A. and Badway, M. (2004). Water quality assessment of the River Nile system: An overview. Biomedical and Environmental Sciences, 17, 87100.

WHO (2004).Guidelines for drinking water quality, $3^{\text {rd }}$ edn, Vol. 1 , Recommendation, Geneva, $515 \mathrm{pp}$. 


\section{توصيف جودة المياه حول كوبرى أسيوط الجديا ومحطته الكهرومائيه \\ ثثابت على محمد طه' و عاطف ابو الوفا احمد` \\ ' 'العلوم البيئية ومعالجة التلوث- معرد السكر - جامعة اسيوط \\ rعميد معهد در اسات و بحوث تكنولوجيا صناعة السكر - جامعة اسيوط - مصر ومعرد}

الملخص:

تم البدء فى مشروع كوبرى اسيوط الجديد ومحطته الكهرومائية فى مـايو r I ب r r

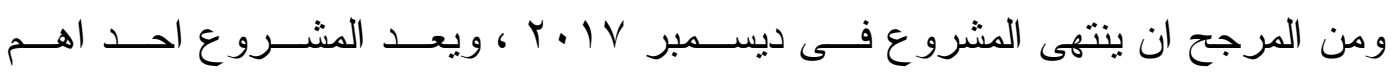
المشروعات الصناعية لخدمة الاقتصاد و التتمية ، وتبلغ الطاقة الكهربيــة للمشـروع بـ بـ ميجا و ات تضخ فى الثبكة الكهربية للمساعدة فى المشروعات التنموية والاسكان ، وفى سبيل ذللك تم جمع العينات من المباة المحيطة بالمشروع وتحليلها وفق الطريقة الامريكيــة للبيئة رقم 979 ا ، و وتم توصيف جودة المياة بتسجيل قيم العو امل الفيزوكيميائية وهـى الاس الهيدروجينى ، المو اد الكلية المذابة ، التوصيل الكهربى للمياة ، الاوكسيجين الذائب

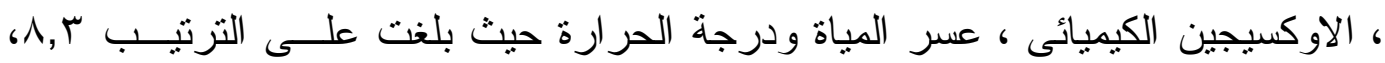

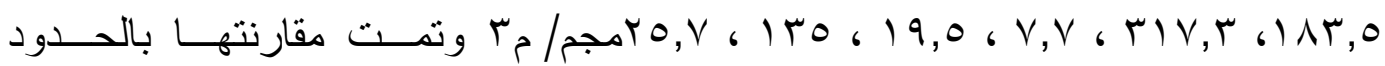

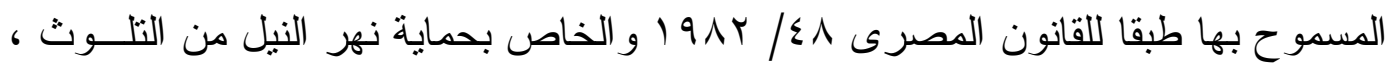
كما تم تعيين الخو اص البيولوجية للمياة وتحديد مو اقع العينات باستخدام نظام الاحــــثاثيات العالمى ، وخلصت الدر اسة الى ان منطقة المياة فى منطقـــة المشــروع مناســبة لاقامـــة المشروعات الصناعية عليهاو ويمثل البحث الحالى در اسة تمهيدية لتقيــيم الاثــار البيئيـــة للمشرو ع فى حالة التشغيل. 